\title{
Influence of Sintering Temperatures on Physico-Mechanical Properties and Microstructure of Refractory Fireclay Bricks
}

\author{
Job Ajala Amkpa ${ }^{\# 1}$, Nur Azam Badarulzaman ${ }^{\# 2}$, Abu Bakar Aramjat*3 \\ ${ }^{\#}$ Faculty of Mechanical and Manufacturing Engineering, Universiti Tun Hussein Onn, Malaysia \\ jobitoh@yahoo.com \\ 2azam@uthm.edu.my \\ "Department of Ceramic Technology and Processing, \\ Kolej Kemahiran Tinggi MARA,78300, Masjid Tanah, Melaka, Malaysia \\ 3abubakararamjat@gmail.com
}

\begin{abstract}
This research emphasized on the influence of sintering temperatures on the microstructure and physico-mechanical properties of Kpata fireclay brick and Qua'an Panfireclay brick were assessed for suitability and application as refractory bricks. The clay samples were sintered at varied temperatures of $900{ }^{\circ} \mathrm{C}, 1000{ }^{\circ} \mathrm{C}, 1100{ }^{\circ} \mathrm{C}$ and $1200{ }^{\circ} \mathrm{C}$. The clay samples were subjected to $\mathrm{X}$-ray diffractometer to analyze the phase transformation after being sintered. The XRD results indicated the finger prints of the phase changes inthe Kpata and Qua'an Pan fireclay bricks.At the best sintering temperature of $1200{ }^{\circ} \mathrm{C}$, phase changes were quartz, mullite, rutile, corundum and cristobalite phases, while Qua'an Panfireclay brick had phase changes of quartz, cristobalite and mullite. SEManalysiswas carried out to observe the surface morphology.The refractoriness of Kpata and Qua'an Pan bricks were $1621{ }^{\circ} \mathrm{C}$ and $1564{ }^{\circ} \mathrm{C}$ respectively. Their cold crushing strength and apparent porosity were investigated.
\end{abstract}

Keyword-SinteringTemperatures, Phase Transformation, Fireclay Brick, Refractoriness.

\section{INTRODUCTION}

The up surge application and request for refractory bricks had motivated this research to investigate the raw clay materials used for production of refractory bricks. The raw clay materials were subjected to standard refractory fireclay brick tests requirement through the tests procedures for chemical, thermal, physical and mechanical properties [1]. Clay as a raw material varied considerably in terms of workability, structure, particle-size distribution, plasticity and mineralogical composition. These differences paved way for clays being categorized or classified into plastic clays, flint clays, kaolin clays, fireclays and ball clays [2]. In the refractory industries, they are grouped and referred to as illite, Montmorillonite and kaolinite [3]. Refractories are clay materials that are generally capable of enduring very high temperatures without deformation, structural changes or softening [4]. The type of refractories is determined by the type of refractory requirement for a specific purpose. The types are classified as acid, basic and neutral refractories [5]. Traditionally these clay materials contain $\mathrm{Al}_{2} \mathrm{O}_{3} \cdot \mathrm{SiO}_{2} \cdot \mathrm{H}_{2} \mathrm{O}$ to produce alumino-silicates refractory fireclay bricks. They are further classified by temperature. When the temperature is between $1500-1700{ }^{\circ} \mathrm{C}$, it is branded as refractory e.g. fireclay.The temperaturebetween $1700-2000{ }^{\circ} \mathrm{Cis}$ recognized as high refractory e.g. chromite. When thetemperature is $>$ $2000{ }^{\circ} \mathrm{C}$, it is referred to as super refractory e.g. zircon[5]. The applications of refractories are employed in the construction of furnaceslinings, ladles, reactors, ovens and kiln [6]. This disposition proved that the raw clay material is a fireclay and belongs to the alumino-silicate subgroup. The uses for fireclay refractory brick comprise of porous refractory insulation behind furnace linings, refractory fireclay bricks and ladles [7].Refractories are frequently consumed basically in the iron and steel industries [8]. Contamination of refractories clays are usually with limited amount of impurity as contained in the oxides which are $\mathrm{CaO}, \mathrm{MgO}$, $\mathrm{TiO}_{2}, \mathrm{Fe}_{2} \mathrm{O}_{3}, \mathrm{Mn}, \mathrm{SO}_{3}, \mathrm{ZnO}, \mathrm{Cl}, \mathrm{K}_{2} \mathrm{O}, \mathrm{P}_{2} \mathrm{O}_{5}, \mathrm{Cr}_{2} \mathrm{O}_{3}$ and alkali oxides that acts as fluxing mediator at very high temperature [9]. In the process ofiron and steel production, the use of basic oxygen furnace (BOF) for the molten iron that comes from the blast furnace is decontaminated from the scums.Refractories belonging to silica-alumina have heterogeneous microstructure with bulky grain size and reasonable rate of porosity[10]. In Nigeria, previous investigation work has been done on the characterization of the native refractory raw clay materials for the making of quality refractory fireclay bricks for furnace lining, ladles, ovens and kilns [11]. In many cases, the outcome and results of such previous work were inconclusive and not comprehensive enough to be used or adopted for industrial uses. They were not subjected to standard test requirement for refractory bricks production. The researches for an alternative using the locally sourced raw material throw a challenge which is surmountable. This development will in no small way conserve foreign exchange for the country [12]. 
Deplorably, \$2.9 billion was being invested and depleted annually on the importation of these refractories [13]. It was on these premises that necessitated and informed the choice of investigation on these clays mentioned.

\section{MATERIALS AND METHODS}

\section{A. Materials}

The clay samples used in this research were collected from Kpata in Bassa local government area of Kogi state and Qua'an Pan in Qua'an Pan local government area of Plateau state, all in North central geo-political zone of Nigeria. The clay samples deposit sites were dogged 2 meters deep into the earth using an iron digger; $20 \mathrm{~kg}$ of the clay samples each were packed with shovel into a plastic bag. The clay samples lumps had an average size of 12-25 cm. The collection and transportation of all the clay samples were according to ASTMD4220/D4220M-14 [14].

\section{B. Methods}

1) Sample preparation: Clay samples were ball milled to form fine powder particles. Each of the specimen powder was pressed into pallets using Caver hydraulic pressing machine. A force of 4 tonnes was applied with a holding time of 60 seconds. The samples were then transferred into furnace and subjected to thermal treatment by sintering process at varied sintering temperatures of $900{ }^{\circ} \mathrm{C}, 1000{ }^{\circ} \mathrm{C}, 1100{ }^{\circ} \mathrm{C}$ and $1200{ }^{\circ} \mathrm{C}$ for 8 hours as soaking time with heating rate of $2.5^{\circ} \mathrm{C} / \mathrm{min}$. The apparent porosity test was performed using the sintered test samplesand the test was conducted according to ASTM C20-2000 [15].The refractoriness test was performed according to ASTM C24-09 [16].

2) Specimen characterization: The X-ray diffraction (XRD) patterns were achieved using a BRUKER D8 ADVANCE machine. The pattern was scanned in series of angles diffraction from $10^{\circ}$ to $80^{\circ}(2 \theta)$ in steps of 0.034 " designed for clay using copper $(\mathrm{CuKa})$ with a wavelength of $1.5406 \AA$ as $\mathrm{X}$-ray source. At various angle, the intensity diffracted are measured and recorded instantly on a chart where the suited $(\theta)$ and (d) values were generated and received. The chemical composition was determined using the Oxford X-Supreme 8000 (XRF) technique. This analytical method is non-destructive, employed to identify the concentration of elements existing in the clay samples. The Scanning Electron Microscopy (SEM), JEOL JSM-6380LA and energy dispersive X-ray spectroscopy (EDX) were used to determine the elements dominate in the fireclay brick specimens and to observe the surface morphology of the Kpata and Qua'an Pan fireclay bricks.

\section{RESULTS AND DISCUSSION}

In the analyzed results of chemical composition of the two clay samples in Table 1, the dominating oxides for the two specimens were $\mathrm{SiO}_{2}$ and $\mathrm{Al}_{2} \mathrm{O}_{3}$. Kpata fireclay brick had $\mathrm{SiO}_{2}$ and $\mathrm{Al}_{2} \mathrm{O}_{3}$ with weight values of $74.8 \%$ and $22.599 \%$ respectively, while Qua'an Panfireclay brick had $\mathrm{SiO}_{3}$ and $\mathrm{Al}_{2} \mathrm{O}_{3}$ with weight values of $63.437 \%$ and $32.673 \%$ respectively. The sintering of refractory bricks can impact strength to a large extent in the bricks products as they become strongerwhen the pose are closed due to rise or increase in sintering temperature [17].The Kpata and Qua'an Pan fireclay bricks fall within the range of temperature $1500-1750^{\circ} \mathrm{C}$ for fireclays according to ASTM classification of refractories by temperature ranges [5].The SEM micrographs were taken on X1500 magnification. Both clay samples showed a remarkable improvement on densification. As sintering temperatures increases, there was progressive improvement on the surface morphology of Kpata and Qua'an Panfireclay bricksas presented in Fig. 1 and Fig. 2. Percentage porosity reduced as sintering temperatureswere increased.

TABLE 1. Chemical composition (\%)

\begin{tabular}{|l|l|l|l|l|l|l|l|l|l|l|l|l|l|}
\hline & $\mathrm{SiO}_{2}$ & $\mathrm{Al}_{2} \mathrm{O}_{3}$ & $\begin{array}{l}\mathrm{Fe}_{2} \mathrm{O} \\
3\end{array}$ & $\mathrm{TiO}_{2}$ & $\mathrm{CaO}$ & $\begin{array}{l}\mathrm{Mg} \\
\mathrm{O}\end{array}$ & $\mathrm{K}_{2} \mathrm{O}$ & $\begin{array}{l}\mathrm{P}_{2} \mathrm{O} \\
5\end{array}$ & $\mathrm{Mn}$ & $\mathrm{SO}_{3}$ & $\begin{array}{l}\mathrm{Cr}_{2} \mathrm{O} \\
3\end{array}$ & $\mathrm{Cl}$ & $\mathrm{ZnO}$ \\
\hline Kpata & 74.87 & 22.59 & 0.60 & 0.90 & 0.09 & 0.21 & 0.15 & 0.22 & 0.02 & 0.29 & 0.29 & 0.17 & - \\
& 6 & 9 & 9 & 7 & 1 & 7 & 6 & 2 & 9 & 6 & 6 & 6 & \\
\hline $\begin{array}{l}\text { Qua'a } \\
\text { n Pan }\end{array}$ & 63.67 & 32.67 & 1.40 & 0.92 & 0.07 & 0.32 & 0.55 & 0.26 & 0.03 & 0.31 & 0.13 & 0.04 & 0.01 \\
8 & 1 & 8 & 3 & 4 & 7 & 8 & 5 & 7 & 4 & 4 & 4 \\
\hline
\end{tabular}



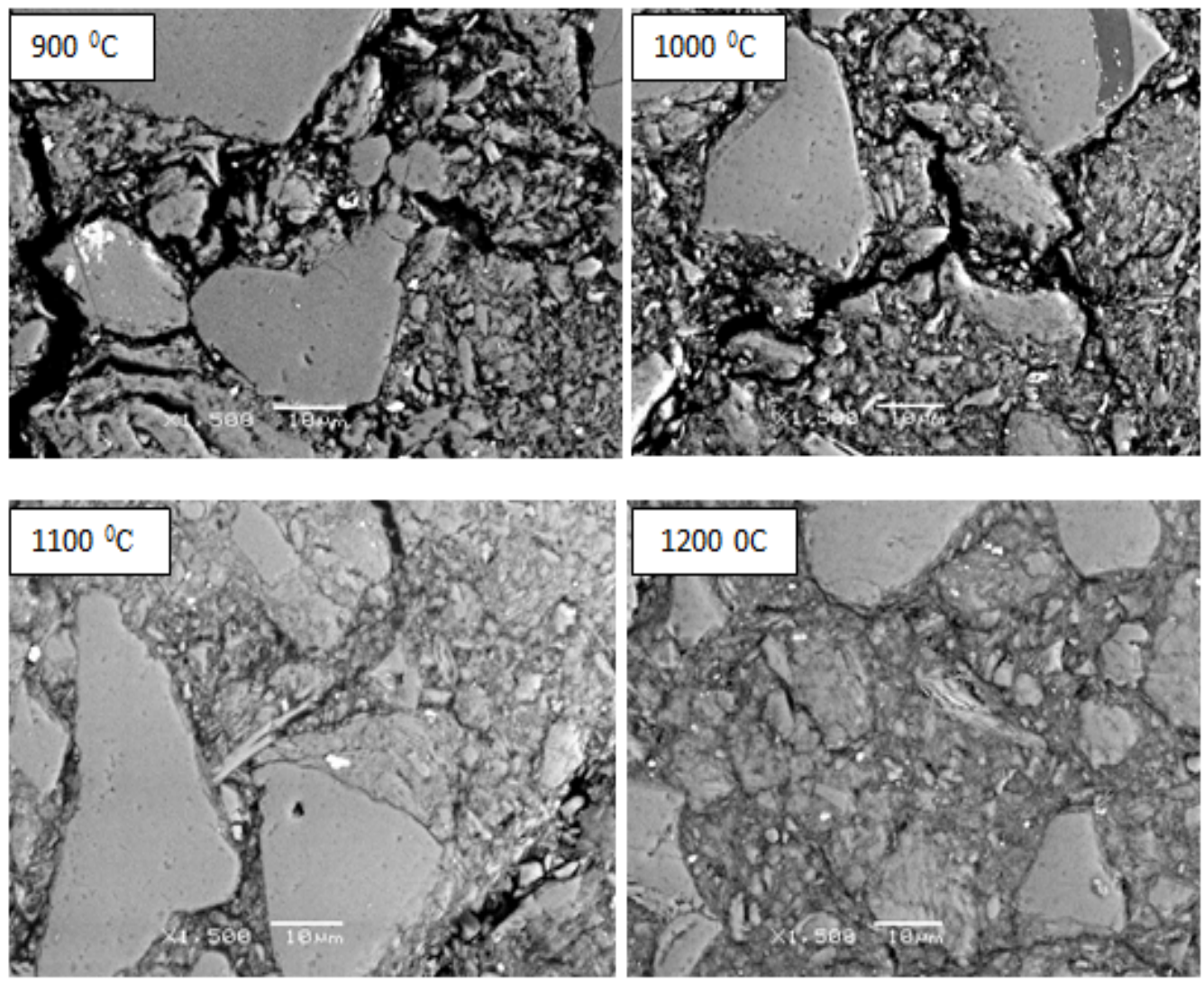

Fig.1: SEM micrographs (X1500) of Kpata fireclay brick and surface morphology at varied sintering temperatures.
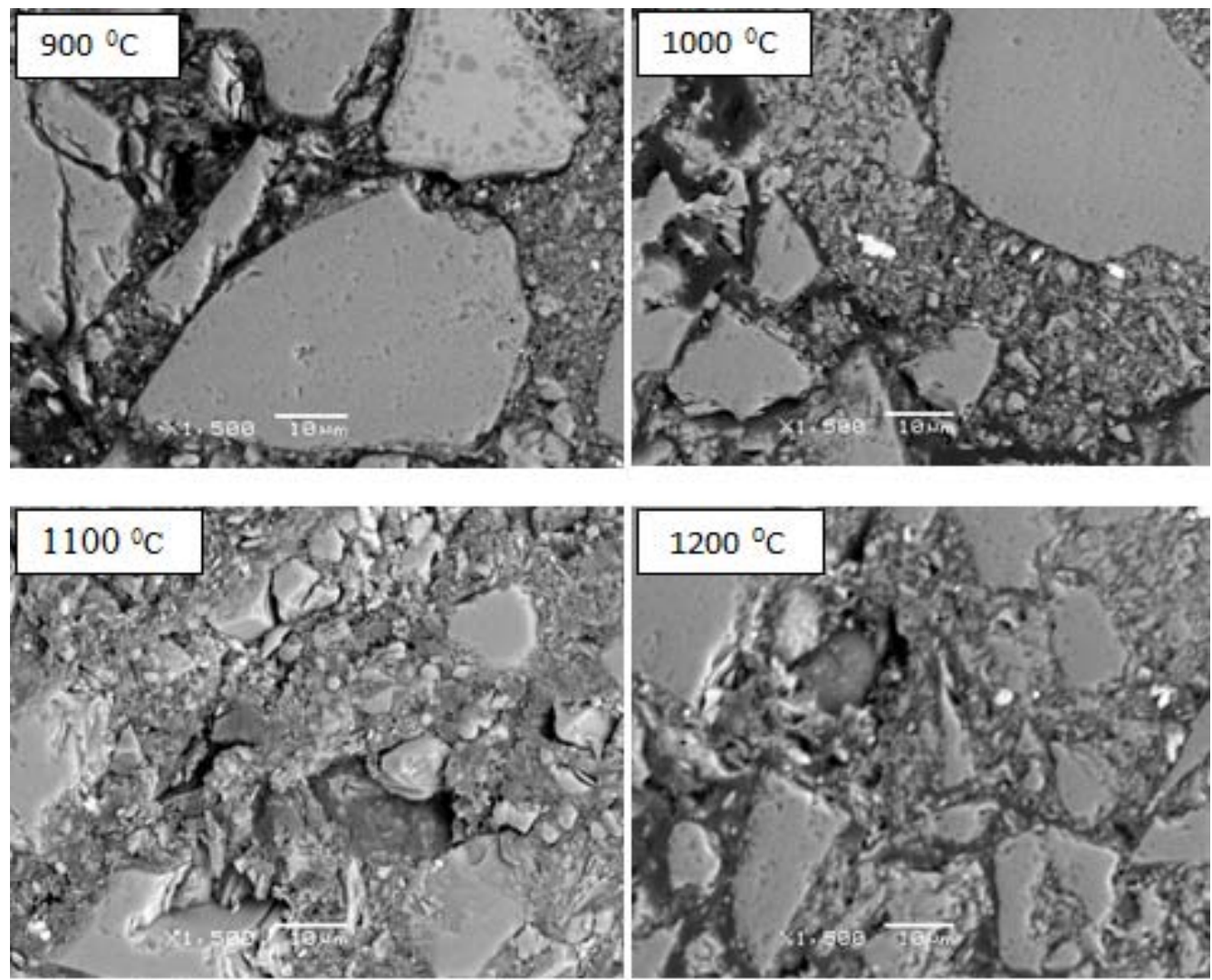

Fig.2: SEM micrographs (X1500) of Qua'an Panfireclay brickand surface morphology at variedsintering temperatures. 


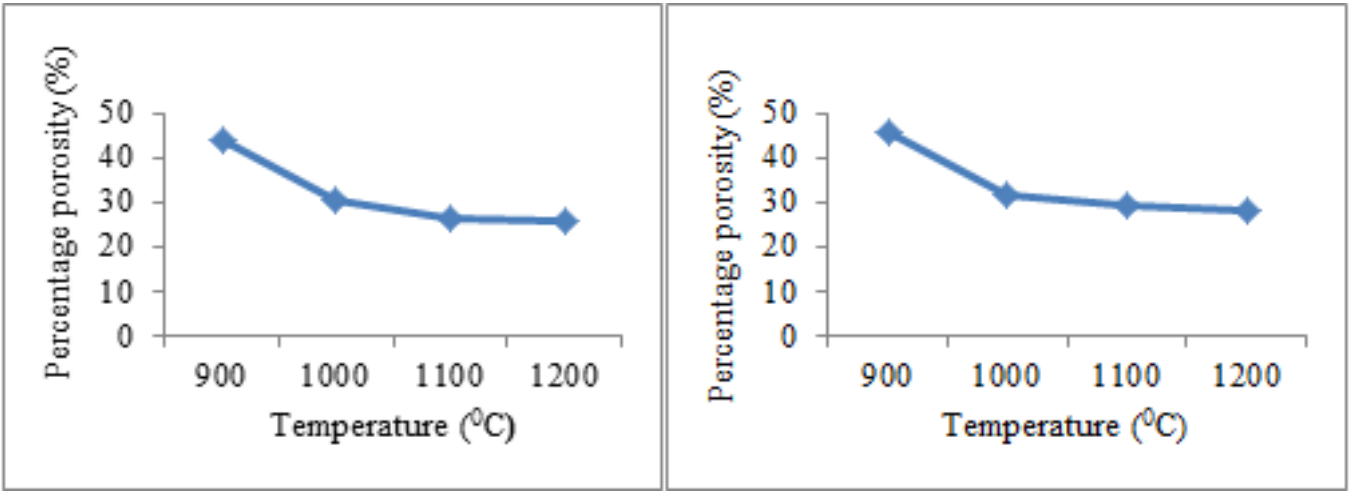

Fig. 3: Percentage porosity against varied sintering temperatures of Kpata and Qua'anPan fireclay bricks.

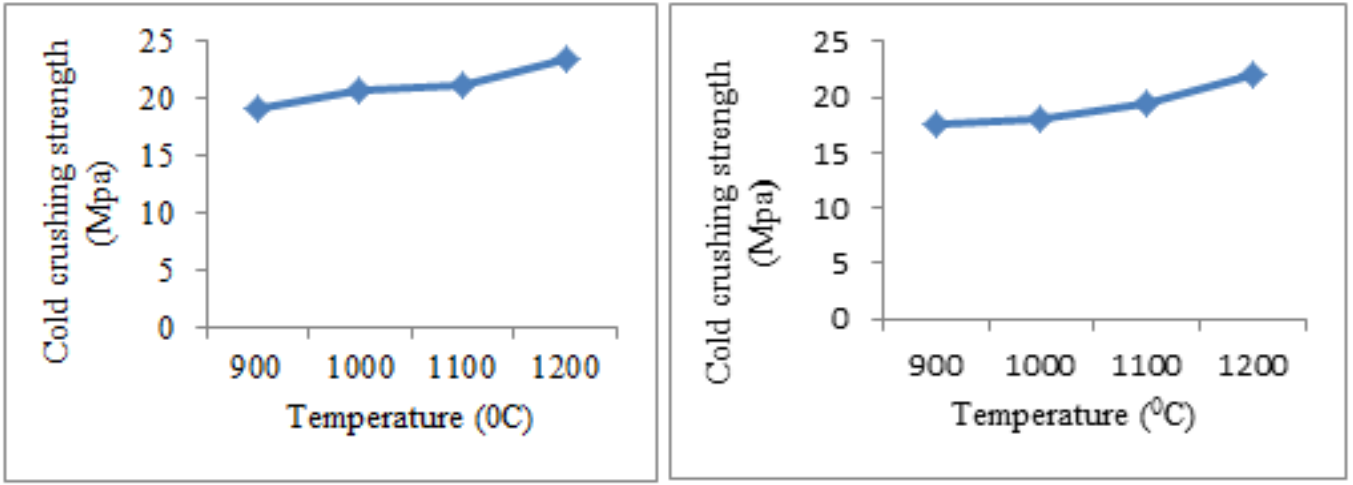

Fig. 4: Cold crushing strength against varied sintering temperatures of Kpata and Qua'an Pan fireclay bricks.

In the evaluation of physical and mechanical chattels, the evaluated results of percentage porosity and cold crushing strength in Fig. 3 and Fig. 4 of Kpata fireclay brick and of Qua'an Pan fireclay brick respectively, exhibited that Kpata fireclay brick had maximum porosity of $43.76 \%$ at $900{ }^{\circ} \mathrm{C}$ sintering temperature, with the minimum porosity of $25.41 \%$ attained at the best sintering temperature of $1200{ }^{\circ} \mathrm{C}$. The $\mathrm{Al}_{2} \mathrm{O}_{3}$ was responsible for the strength in the clay material. The Qua'an Panfireclay brick had the highest porosity of $45.6 \%$ at $900{ }^{0} \mathrm{C}$ sintering temperature and the lowest porosity of $27.73 \%$ at the best sintering temperature of $1200{ }^{0} \mathrm{C}$. The Qua'an Panfireclay brick had the highest $\mathrm{Al}_{2} \mathrm{O}_{3}$ content than Kpatafireclay brick as stated in Table $1 . \mathrm{Al}_{2} \mathrm{O}_{3}$ (Alumina) increases strength inthe clay material. The percentage porosity of the Kpata and Qua'an Pan fireclay bricks fell within the standard values of 20-30\% for fireclay refractory bricks [4] [13].

In terms of mechanical properties, the Kpata fireclay brick had the high cold crushing strength of $23.36 \mathrm{MPa}$ at optimum sintering temperature of $1200{ }^{0} \mathrm{C}$ as against the lowest strength of $19.12 \mathrm{MPa}$ at $900{ }^{0} \mathrm{C}$ sintering temperature. The Qua'an Pan fireclay brick had the highest cold crushing strength of $21.97 \mathrm{MPa}$ at optimal sintered temperature of $1200{ }^{\circ} \mathrm{C}$ and the lowest strength of $17.64 \mathrm{MPa}$ at $900{ }^{\circ} \mathrm{C}$ sintering temperature. The cold crushing strength also improved and increased as the sintering temperature was increased [17].The cold crushing strength (mechanical strength) of the Kpata and Qua'an Pan fireclay bricks fell within the standard values of 15$59 \mathrm{MPa}$ for refractories [4]. 


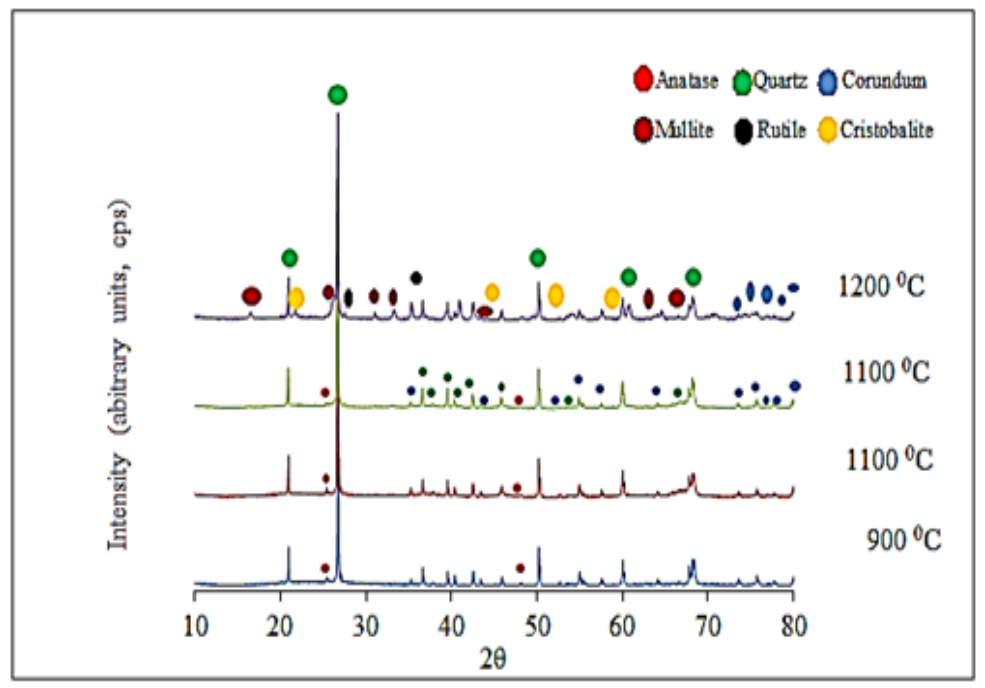

Fig 5: XRD pattern of Kpata fireclay brick.

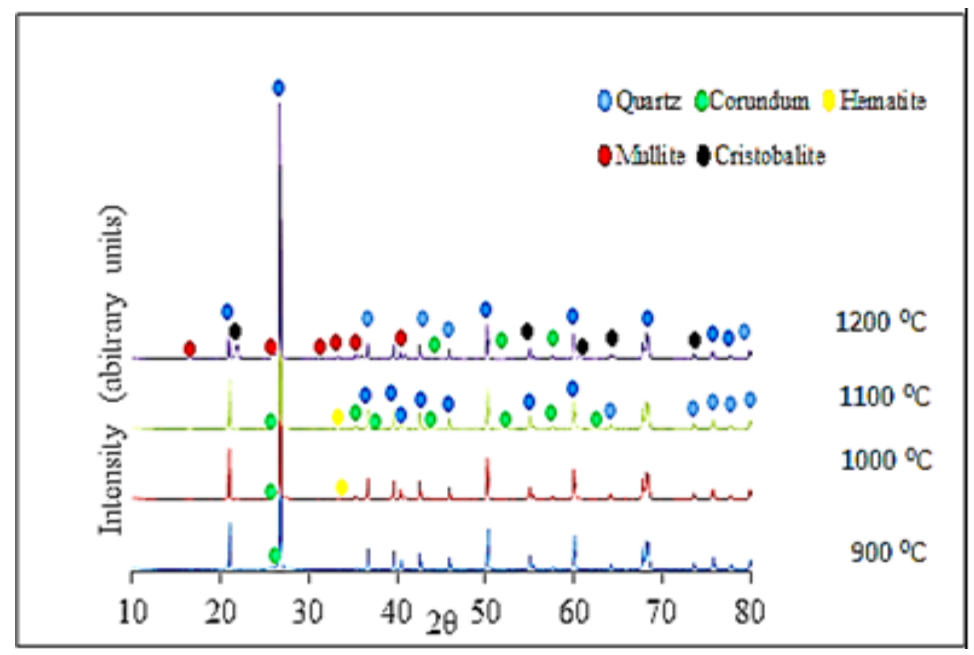

Fig 6: XRD pattern of Qua'an Pan fireclay brick.

The X-ray diffraction (XRD) results of the two clay deposits showed the crystallization and phase transformation at varied sintering temperatures.A very close observation on the Kpata clay deposit showed phase changes of quartz, corundum, anatase, rutile, mullite and cristobalite presented in Fig. 5, while Qua'an Panclay manifestedphase transformation of quartz, corundum, hamatite, mullite and cristobaliteshown in Fig. 6. The refractoriness of the clay samples were done one after the other by shaping the sample into a conical form. The standard pyrometric Segar cones of numbers 28, 29 and 30 of known softening temperatures were arranged on a standard circular shaped plaque with the aid of a binder. The cones at an angle of $82^{0}$ to the horizontal were fixed on the plaque. It was then transferred to the refractoriness testing equipment and fired. The observation with the aid of a mirror attached to the refractoriness heating equipment, the PCE cone bent at firing temperature of $1621{ }^{\circ} \mathrm{C}$ which corresponded to the equivalent of segar cone No: 29, hence, the refractoriness for Kpata fireclay bricks and this qualifiedthe sample as high duty (Siliceous) brick. Similarlly, the same PCE test was conducted for the Qua'an Pan fireclay brick using segar cones 19, 20 and 23. Its refractoriness was $1564{ }^{0} \mathrm{C}$ which corresponded to segar cone No: 20 and qulified as low heat duty brick. Both refractory bricks qualified as fireclay bricks according to ASTM C27-98 [5]. The refractoriness of the two fireclay bricks fell within the standard refractoriness of $1500-1750{ }^{\circ} \mathrm{C}$ for fireclay refractories [13] [18].

\section{CONCLUSION}

The stability and suitability of Kpata and the Qua'an Pan claysarebased on their results of refractoriness, apparent porosity, cold crushing strength, SEM and XRD are adequate and appropriate to be used for production of refractory bricks. 


\section{ACKNOWLEDGEMENT}

The authors would like to acknowledge Universiti Tun Hussein Onn Malaysia, ORICC for the Graduate Research Incentive Grant (Vot No: U293), Centre for Graduate Studies, Faculty of Mechanical and Manufacturing Engineering. We would also like to acknowledge Fazlannuddin H.H. of the Polymlar Lab, M. Tamizi and Anuar Ismail of Material Science Lab.

\section{REFERENCES}

[1] S. Otroj, and A. Daghighi, "Microstructure and phase evolution of alumina-spinel self-flowing refractory castables containing nanoalumina particles," Ceramics International, vol. 37, no. 3, p. 1003-1009, 2011.

[2] A. Andrews, S. K. Gawub, and P. A. Olubambi, "Fireclay bricks produced from lithomargic clay," Journal of Ceramic Processing Research, vol. 16, no. 1, p. 37-40, 2015.

[3] F. Momade, and S. Gawu, "Geochemical and mineralogical characteristics of lithomargic clay types from Awaso bauxite deposit, Ghana: implications for possible industrial utilization," Journal of Science and Technology (Ghana),vol. 29, no. 2, p.96-106, 2009.

[4] A. A. Jock, F. A. Ayeni, A. S. Ahmed, and U. A. Sullayman, "Evaluation of the refractory properties of Nigerian Ozanagogo clay deposit," Journal of Minerals and Materials Characterization and Engineering, vol. 1,p. 321-325, 2013.

[5] ASTM C27—98, "Standard classification of fireclay and high-Alumina Refractory bricks," ASTM International, vol. 15 (1) 2008.

[6] S. Hassan, "Modern Refractories: Production, Properties, Testing and Application," Timo Commercial Printers Samaru, Zaria, p. 1322, 2005.

[7] J. H. Chesters, "Refractories--Production and Properties," Iron and Steel Institute, London. p.3-63, 1973.

[8] C. Sadik, I.-E. El Amrani, and A. Albizane, "Recent advances in silica-alumina refractory: a review," Journal of Asian Ceramic Societies, vol. 2, no. 2, p. 83-96, 2014.

[9] A. Andrews, J. Adam, and S. K. Gawu, "Development of fireclay aluminosilicate refractory from lithomargic clay deposits," Ceramics International, vol. 39, no. 1, p. 779-783, 2013.

[10] P. Jacques, "Refractory Ceramics from Elaboration to use properties," Glass Ceramics \& composites, vol. 1, p. 28-42, 2010.

[11] D. E. Esezobor, F. I. Apeh, M. O. Udo, M. Fabiyi, and E. S. Apeh, "Evaluation of Cost Effectiveness of Onibode Fire-Clay for Production of High Quality Refractory Bricks," Journal of Minerals and Materials Characterization and Engineering, vol. 3, no. 05, p. 399, 2015.

[12] S. Hassan, "Effects of silicon carbide on some refractory properties of Kankara clay," Journal of applied science, Engineering and technology, vol. 5, no. 1, p. 21-26, 2006.

[13] F. I. Apeh, D. E. Esezobo, and G. I. Lawal, "Characterization of Onibode and Owode-Katu Fireclay for use as Refractory Materials in Foundry Industry,” Journal of Engineering Research, no. 16, p. 69-77, 2011.

[14] ASTM-D4220/D4220M-14, "Standard Practices for Preserving and Transporting Soil Samples," ASTM International, vol.15 (1) 2014.

[15] ASTM C20-00: Standard Test Method for Apparent Porosity, Water Absorption, Specific gravity and Bulk Density, ASTM International, vol. 15 (1) 2015.

[16] ASTM C24-09: Standard Test Method for Pyrometric Cone Equivalent (PCE) of Fireclay and High Alumina Refractory Materials, ASTM International, vol. 15 (1) 2013.

[17] H. Hamisi, E. Park, H. Choi, Y. An, and J. Lee, "Influence of firing temperature on physicalproperties of Same Clay and Pugu Kaolin for Ceramic Tile Application,” International Journal of Materials Science and Applications, vol. 3, no.5, p. 143-146, 2014.

[18] America Society of Testing Materials: Standard forRefractories, Glass, and other Ceramic Materials: Manufactured Carbon and Graphite Products. Part 17 (1976).

\section{AUTHOR PROFILE}

Job Ajala Amkpa PhD candidate Faculty of Mechanical and Manufacturing Engineering

Nur Azam BadarulzamanSenior Lecturer at the Department of Materials and Design Engineering

Abu Bakar Aramjat Lecturer in Ceramic Processing Technology Center, Kolej Kemahiran Tinggi MARA 